\title{
Analisis Perubahan Pemanfaatan Ruang di Kota Pekanbaru Studi Kasus :Koridor Ruas Jalan Soekarno Hatta
}

\section{Yendri Rizki, Febby Asteriani}

\author{
Program Studi Teknik Perencanaan Wilayah dan Kota, Universitas Islam Riau \\ Jln.Kaharuddin Nasution no.113 Marpoyan Damai - Pekanbaru - Riau \\ Email : febby.uir.fr@gmail.com
}

\begin{abstract}
Abstrack
Pekanbaru City as the capital of Riau Province has a quite rapidly development. One of the areas that is undergoing rapid change is the Soekarno-Hatta road segment. This corridor is located in a commercial and educational area. Strategic location makes this corridor an attraction for the community and investors to invest in the region. The purpose of this study was to analyze changes in spatial use in the corridor of Soekarno Hatta Street in Pekanbaru City in 2008-2018. This researcher used a qualitative descriptive method, with spatial overlay analysis techniques in 2008 and 2018 using GIS. The results of this study are the use of space in 2008-2018 experienced a lot of changes in land use change and increased space use. In 2008 the use of space in the corridor of Soekarno Hatta Street was still largely in the form of vacant land, which has not been utilized. Most of the changes in spatial use are the emergence of new areas of land that have not been utilized. In addition, an increase in the area of spatial use for economic activities amounted to $301,455 \mathrm{~m} 2$, the area of social activity change increased by $17,014 \mathrm{~m} 2$, and the area of settlement changes decreased by $10,303 \mathrm{~m} 2$. A significant change in spatial use is in the form of increasingly widespread commercial activity in the strategic corridor area.
\end{abstract}

Keywords: utilization, space, corridor, road section, commercial area

\begin{abstract}
Abstrak
Kota Pekanbaru sebagai ibukota Provinsi Riau telah mengalami perkembanganyang cukup pesat. Salah satu kawasan yang mengalami perubahan cukup pesat tersebut adalah koridor ruas Jalan Soekarno Hatta. Koridor ini berada di kawasan komersial dan kawasan pendidikan. Lokasi yang strategis membuat koridor ini menjadi daya tarik bagi masyarakat dan investor untuk berinvestasi di kawasan tersebut. Tujuan penelitian ini adalah menganalisis perubahan pemanfaatan ruang di koridor ruas Jalan Soekarno Hatta Kota Pekanbaru pada tahun 2008-2018. Penelitian ini menggunakan metode desktiptif kualitatif, dengan teknikanalisis spasial overlay tahun 2008 dan 2018 menggunakan GIS.Hasil dari penelitian ini adalahbahwa pemanfaatan ruang tahun 2008-2018 banyak mengalami perubahan alih fungsi lahan dan peningkatan pemanfaatan ruang.Pada tahun 2008 pemanfaatan ruang dikoridor ruas Jalan Soekarno Hatta masih banyak berupa lahan kosong yang belum ada pemanfaatan. Perubahan pemanfaatan ruang yang terjadi, sebagian besar adalah munculnya kawasan baru dari lahan yang belum termanfaaatkan.Selain itu, terjadi peningkatan luas pemanfaatan ruang untuk kegiatan ekonomi sebesar $301.455 \mathrm{~m}^{2}$, luas perubahan kegiatan sosial bertambah sebesar $17.014 \mathrm{~m}^{2}$, dan luas perubahan permukiman berkurang sebesar $10.303 \mathrm{~m}^{2}$. Perubahan pemanfaatan ruang yang signifikan adalah berupa kegiatan komersial yang semakin meluas pada kawasan strategis koridor.

Kata kunci: pemanfaatan, ruang, koridor, ruas jalan, kawasan komersial
\end{abstract}




\section{PENDAHULUAN}

Kota adalah tempat dengan konsentrasi penduduk lebih padat dari wilayah sekitarnya karena terjadi pemusatan kegiatan fungsional yang berkaitan dengan kegiatan atau aktifitas penduduknya (Nia, 2008). Kota dalam tinjauan fisik atau morfologi menekankan pada bentukbentuk kenampakan fisikal dari lingkungan kota. Smailes dalam Yunus (2000) memperkenalkan 3 unsur morfologi kota yaitu penggunaan lahan, pola-pola jalan dan tipe atau karakteristik bangunan. Sementara itu Conzen dalam Yunus (2000) juga mengemukakan unsur -unsur yang serupa dengan dikemukakan Smailes, yaitu plan architectural style and land use. Berdasarkan pada berbagai macam unsur morfologi kota yang dikemukakan secara umum unsur-unsur morfologi kota berkisar antara karakteristik bangunan, pola jalan dan penggunaan lahan. Pola jaringan jalan merupakan salah satu elemen dalam morfologi perkotaan (Asteriani dkk, 2019).

Perkembangan suatu kota pada hakekatnya dipengaruhi oleh pertumbuhan, dimana kota sebagai wadah fisik yang berkembang dan bertumbuh dari segala macam kegiatan masyarakat kota. Pusat pertumbuhan adalah suatu pusat yang memiliki medan daya untuk menarik elemen-elemen pertumbuhan terutama elemen ekonomi untuk masuk dan meningkatkan kegiatan yang ada didalamnya seperti kegiatan industri dan semacamnya (Kuklinski dalam Indra, 2016).

Perkembangan kota yang paling mudah untuk dipahami adalah dengan perkembangan fisik spasial kota. Perkembangan spasial suatu kota ditandai dengan dua cara, yaitu perkembangan spasial kota secara horizontal dan perkembangan spasial secara vertikal. Pada dasarnya perkembangan lahan terbangun dalam suatu kawasan disebabkan oleh adanya perubahan penggunaan lahan yang terjadi di kawasan tersebut. Perubahan penggunaan lahan adalah dari satu sisi penggunaan ke penggunaan yang lainnya.

Perkembangan spasial secara horizontal dilakukan dengan melakukan perluasan terhadap wilayah perkotaan. Perkembangan spasial secara horizontal mengakibatkan perubahan fungsi lahan

di pinggiran kota sehingga akan berdampak pada kehadiran ruang terbuka hijau yang akan semakin berkurang dengan terjadinya perkembangan secara horizontal ini

Perkembangan kota secara vertikal dapat di artikan sebagai bentuk penambahan ruang kota dengan menambah jumlah lantai bangunan (Yunus, 2005). Namun dalam perkembangannya, pembangunan kota secara vertikal harus memiliki ketahanan tanah memadai untuk menopang bangunan dengan lantai yang banyak.

Dalam Undang-Undang Penataan Ruang No.26 Tahun 2007, Pemanfaatan ruang adalah upaya untuk mewujudkan struktur ruang dan pola ruang sesuai dengan rencana tata ruang melalui penyusunan dan pelaksanaan program beserta pembiayaannya. Ketentuan umum tentang pemanfaatan ruang ditegaskan dalam Pasal 32 Undang-Undang Penataan Ruang sebagai berikut:

1. Pemanfaatan ruang dilakukan melalui pelaksanaan program pemanfaatan ruang beserta pembiayaannya.

2. Pemanfaatan ruang sebagaimana dimaksud pada ayat (1) dapat dilaksanakan dengan pemanfaatan ruang, baik pemanfaatan ruang secara vertikal maupun pemanfaatan ruang di dalam bumi.

3. Program pemanfaatan ruang beserta pembiayaannya sebagaimana dimaksud pada ayat (1) termasuk jabaran dari indikasi program utama yang termuat di dalam rencana tata ruang wilayah.

4. Pemanfaatan ruang diselenggarakan secara bertahap sesuai dengan jangka waktu indikasi program utama pemanfaatan ruang yang ditetapkan dalam rencana tata ruang.

5. Pelaksanaan pemanfaatan ruang di wilayah sebagaimana dimaksud pada ayat (3) disinkronisasikan dengan pelaksanaan 
pemanfaatan ruang wilayah administratif sekitarnya.

6. Pemanfaatan ruang sebagaimana dimaksud pada ayat (1) dilaksanakan dengan memperhatikan

standar pelayanan minimal dalam penyediaan sarana dan prasarana.

Perubahan penggunaan lahan yang terjadi, pada dasarnya bersifat dinamis mengikuti perkembangan penduduk dan pola pembangunan wilayah. Akan tetapi perubahan pola penggunaan lahan yang tidak terkendali dan terencana dapat berpengaruh buruk terhadap daya dukung lahan yang pada akhirnya dapat berpengaruh buruk terhadap pembangunan itu sendiri dan pembangunan semacam ini tidak akan berkelanjutan. Perubahan atau perkembangan pola penggunaan lahan dipengaruhi oleh dua fakor utama, yaitu faktor alami dan faktor manusia. Faktor alami antara lain: 1) tanah, 2) air, 3) iklim, pola musiman, dan 4) landform, erosi dan kemiringan lereng. Faktor manusia mempengaruhi lebih dominan dibandingkan faktor alami dan dipengaruhi oleh keadaan sosial ekonomi dan pengaruh dari luar, seperti kebijakan nasional dan internasional (Saepul, 2015).

Kota Pekanbaru merupakan ibukota Provinsi Riau yang juga mengalami pertumbuhan dan perkembangan kota sangat pesat. Penampakan fisik Kota Pekanbaru saat ini dapat dilihat terjadi pembangunan di setiap kawasan baik infrastruktur dasar maupun aktifitas lainnya. Dampak dari pertumbuhan dan perkembangan dari kota tersebut menciptakan pusat-pusat pertumbuhan yang memberi pengaruh besar terhadap perkembangan maupun pertumbuhan kota.Salah satu bentuk ruang yang berfungsi sebagai tempat aktifitas atau sebagai interaksi sosial masyarakat di Kota Pekanbaru adalah koridor ruas Jalan Soekarno Hatta yang berada diantara Kecamatan Marpoyan Damai dan Kecamatan Tampan.

Koridor ruas Jalan Soekarno Hatta termasuk kedalam jaringan jalan arteri yang mempunyai peranan penting dalam mobilitas perkotaan yang mana Jalan Soekarno Hatta dapat menghubungkan berbagai tempat komersil yang ada di Kota Pekanbaru. Koridor ruas Jalan Soekarno Hatta berada di Wilayah Pengembangan V yang arahan dan rencana fungsinya sebagai pusat kegiatan pendidikantinggi, kawasan permukiman, pusat kegiatan industri kecil, kawasan perkantoran dan kawasan perdagangan.

Seperti wilayah peri urban pada umumnya, ruas Jalan Soekarno Hatta yang juga banyak mengalami perubahan pemanfaatan ruang, dalam

Yunus (2000) bahwa proses perkembangan spasial secara horisontal menjadi penentu bertambah luasnya areal perkotaan. Artinya, bahwa akselerasi pembangunan pada ruas Jalan Soekarno mengalami proses perubahan pemanfaatan ruang yang berlangsung secara revolusioner dan menunjukkan makin padatnya areal bangunan. Dengan demikian, kondisi tersebut dapat dirumuskan sebagai suatu proses ekspansi dan penambahan keruangan secara mendatar dengan cara menempati ruang-ruang yang masih kosong.

Perubahan pemanfaatan ruang yang terjadi di koridor Jalan Soekarno Hatta disebabkan oleh berbagai faktor seperti keberadaan kawasan perdagangan yang semakin berkembang dimana kawasan koridor Jalan Soekarno Hatta termasuk kedalam jalan arteri primer. Faktor-faktor tersebut cukup memberikan daya tarik bagi investorinvestor untuk menanamkan saham mereka yang disebabkan oleh lokasi Jalan Soekarno Hatta ini berada di posisi yang strategis untuk kegiatan aktivitas perdagangan. Selain aktifitas perdagangan koridor Jalan Soekarno Hatta juga menjadi daya tarik investor untuk membangun hotel dan pusat-pusat perbelanjaan sehingga menyebabkan perubahan dalam pemanfaatan ruang di Koridor Jalan Soekarno Hatta. Perkembangan ruang pada koridor Jalan Soekarno Hatta yang memanjang secara linier merupakan daerah terbangun. Realitas ini sejalan dengan yang dikemukan oleh Babcock dalam Yunus (2005) dalam teori poros bahwa keberadaan poros transportasi akan mengakibatkan pertumbuhan daerah kekotaan karena disepanjang jalur ini berasosiasi dengan mobilitas yang tinggi.

Perubahan pemanfaatan ruang koridor Jalan Soekarno Hatta dicirikan kearah pengembangan aktifitas perkotaan yang beragam dan kompleks secara berkelanjutan, sehingga perkembangan yang berlangsung memiliki pengaruh yang segnifikan terhadap perubahan struktur ruang, 
pola ruang dan keberagaman morfologi pada koridor ruas Jalan Soekarno Hatta. Dengan demikian, berdasarkan latar belakang diatas perlu dilakukan penelitian mengenai Analisis Perubahan Pemanfaatan Ruang Koridor Ruas Jalan Soekarno Hatta Kota Pekanbaru.

\section{METODELOGI PENELITIAN}

Pendekatan penelitian dalam kajian perubahan pemanfaatan ruang koridor ruas Jalan Soekarno Hatta meliputi pendekatan deskriptif yaitu mendeskripsikan perubahan pemanfaatan ruang yang terjadi di koridor ruas jalan soekarno hatta selama sepuluh tahun (2008-2018). Deskriptif menurut Sugiyono (2012) adalah metode yang berfungsi untuk mendeskripsikan atau memberi gambaran terhadap objek yang di teliti melalui data atau sampel yang telah terkumpul sebagaimana adanya, tanpa melakukan analisis dan membuat kesimpulan yang berlaku umum.

Lokasi penelitian perubahan pemanfaatan ruang ini adalah koridor ruas Jalan Soekarno Hatta kota pekanbaru, yang berada diantara kecamatan marpoyan damai dan kecamatan tampan yang mana lokasi ini termasuk ke wilayah pengembangan $\mathrm{V}$ kota Pekanbaru. Wilayah penelitian ini juga tidak jauh dari kawasan pendidikan. Kawasan pendidikan dapat memunculkan pusat pertumbuhan baru (wardhana,dkk). Wilayah penelitian di bagi menjadi 3 segmentasi. Segmen pertama terletak di antara Kelurahan Tengkareng Barat dan Kelurahan Delima dan segmen ketiga terletak antara Kelurahan Sidomulyo Timur dan Kelurahan Delima dan segmen kedua terletak diantara segmen pertama dengan segmen ketiga dengan deliniasi \pm 100 meter kiri kanan atau bangunan paling depan koridor yang berjarak \pm 4 $\mathrm{km}$.

Untuk mendapatkan infromasi menegenai perubahan penggunaan ruang di koridor ruas Jalan Soekarno Hatta kota pekanbaru maka dilakukanlah

penyebaran kuisioner kepada kepada kelompok keluarga yang tinggal di koridor ruas Jalan Soekarno Hatta yaitu di kecamatan marpoyan damai dan kecamatan tampan. Teknik pengambilan sampel yang akan digunakan adalah teknik cluster random samplingyang mana untuk menentukan penduduk mana yang akan dijadikan sumber data, maka pengambilan sampelnya berdasarkan daerah populasi yang telah ditetapkan dan semua masyarakat mempunyai kesempatan yang sama untuk terpilih sebagai sampel.

Metode analisis yang akan digunakan dalam penelitian ini adalah metode deskriptif komparatif dan metode spasial. Alat analisis yang digunakan adalah analisis spasial dan analisis deskriptif

komparatif. Penelitian komparatif menurut Sugiyono (2014) adalah penelitian yang membandingkan keadaan satu variabel atau lebih pada dua atau lebih sampel yang berbeda, atau dua waktu yang berbeda. Pada penelitian ini penelitian komparatif digunakan untuk mengetahui perkembangan dan perubahan pemanfaatan ruang koridor ruas Jalan Soekarno Hatta dalam kurung waktu 10 tahun.

\section{HASIL DAN PEMBAHASAN}

Untuk melihat perkembangan dan perubahan ruang di koridor ruas Jalan Soekarno Hatta Kota Pekanbaru akan menggunakan metoder overlaydata yang akan dibutuhkan dalam overlay ini adalah citra Kota Pekanbaru tahun 2008, citra Kota Pekanbaru tahun 2013 dan citra Kota Pekanbaru 2018. Kemudian peta citra ini di digitasi untuk menghasilkan peta penggunaan lahan tahu 2008, peta penggunaan lahan 2013 dan peta penggunaan lahan 2018 sehingga hasil overlay ini akan menghasilkan peta perubahan pemanfaaatan rauang dikoridor ruas Jalan Soekarno Hatta Kota Pekanbaru 2008-2018.

Pada tahun 2008 pemanfaatan ruang dikoridor ruas Jalan Soekarno Hatta masih banyak berupa lahan kosong yang belum ada pemanfaatan kondisi ini sangat berbanding terbalik dengan kondisi pada saat ini, untuk lebih jelasnya dapat dilihat pada tabel berikut ini:

Tabel 1. Pemanfaatan Ruang di koridor Jalan Soekarno HattaTahun 2008

\begin{tabular}{llr}
\hline No & \multicolumn{1}{c}{ Pemanfaatan Ruang } & \multicolumn{1}{c}{ Luas $\left(\mathbf{m}^{2}\right)$} \\
\hline 1 & Kegiatan Ekonomi & 377.542 \\
2 & Kegiatan Sosial & 2.533
\end{tabular}




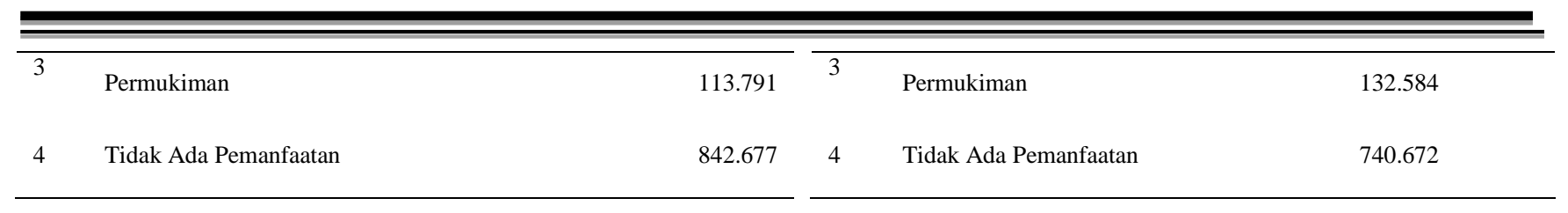

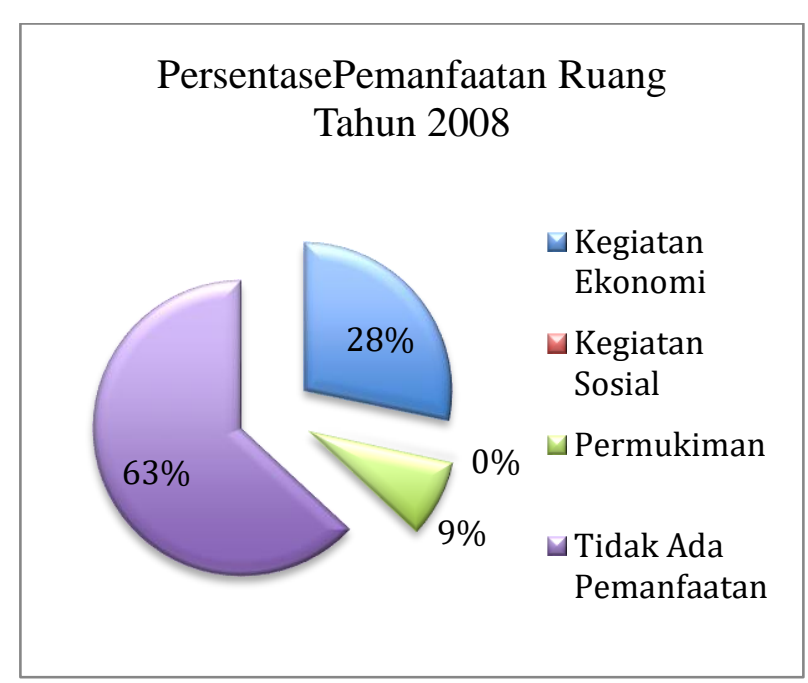

Gambar 1.

Persentase pemanfaatan ruang dikoridor Jalan Soekarno Hatta tahun 2008

Pemanfatan ruang dikoridor ruas jalan soekarno hatta pada tahun 2008 masih banyak lahan kosong yang belum dimanfaatkan sebesar $842.677 \mathrm{~m}^{2}$ atau sebesar 63\%, kemudian dimanfaatkan untuk kegiatan ekonomi $377.542 \mathrm{~m}^{2}$, luas lahan untuk permukiman adalah $113.791 \mathrm{~m}^{2}$ selebihnya dimanfaatkan untuk kegiatan sosial sebesar $2.533 \mathrm{~m}^{2}$ dengan melihat luas dan persentase luas diatas dapat disimpulkan bahwa koridor ruas jalan soekarno hatta kota pekanbaru pada tahun 2008 pemanfaatan lahannya masih dominan lahan non terbangun dibandingkan lahan terbangunnya.

Pemanfaatan ruang pada tahun 2013 dikoridor ruas Jalan Soekarno Hatta Kota Pekanbaru dapat dilihat pada tabel dan gambar berikut:

Tabel 2. Pemanfaatan Ruang Tahun 2013 di koridorJalan Soekarno Hatta

\begin{tabular}{lll}
\hline No & \multicolumn{1}{c}{ Pemanfaatan Ruang } & Luas $\left(\mathbf{m}^{2}\right)$ \\
\hline 1 & Kegiatan Ekonomi & 474.624 \\
2 & Kegiatan Sosial & 15.301 \\
\hline
\end{tabular}

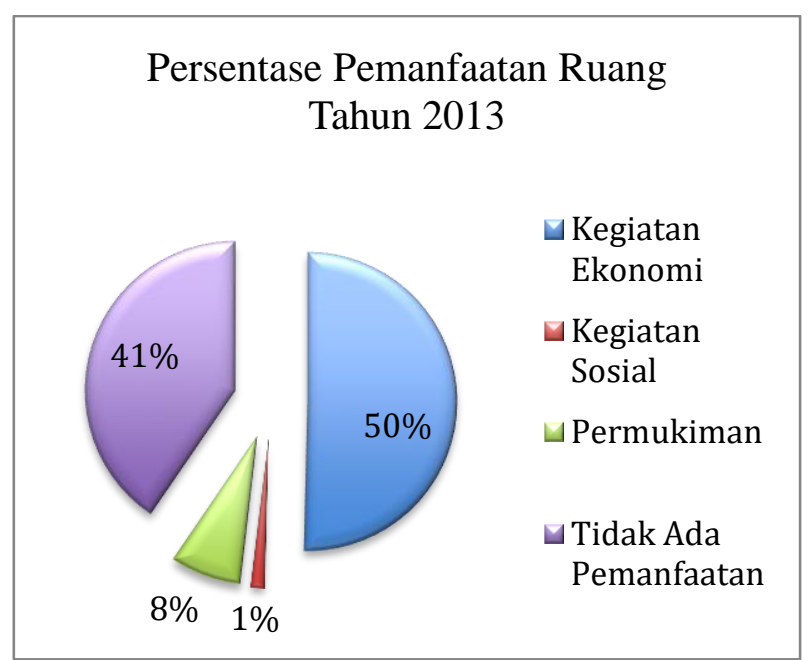

Gambar 2.

Persentase pemanfaatan ruang dikoridor Jalan Soekarno Hatta tahun 2013

Pemanfaatan ruang di koridor ruas Jalan Soekarno Hatta Kota Pekanbaru pada tahun 2013 luas untuk kegiatan ekonomi adalah sebesar $474.624 \mathrm{~m}^{2}$ atau $35 \%$ dari luas wilayah penelitian, luas lahan untuk permukiman $132.139 \mathrm{~m}^{2}$ atau $10 \%$ dari total luas wilayah penelitian, luas wilayah yang tidak ada pemanfaatan $740.672 \mathrm{~m}^{2}$ atau $54 \%$ dari total luas koridor yang menjadi wilayah penelitian, luas lahan untuk kegiatan sosial adalah $15.301 \mathrm{~m}^{2}$. Atau $1 \%$ dari total luas wilayah penelitian.

Selanjutnya, pemanfaatan ruang pada tahun 2018 dikoridor ruas Jalan Soekarno Hatta Kota Pekanbaru dapat dilihat pada tabel dan gambar berikut: 
Persentase Pemanfaatan Ruang Tahun 2018

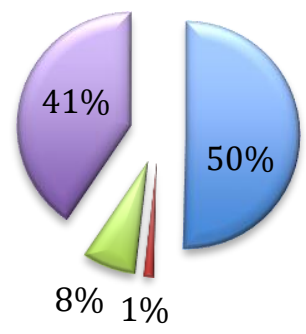

$\square$ Kegiatan

Ekonomi

$\square$ Kegiatan Sosial

$\square$ Permukiman

Gambar 3.

Persentase pemanfaatan ruang dikoridor Jalan Soekarno Hatta Tahun 2018

\begin{tabular}{|c|c|c|c|}
\hline 2013 & 2018 & $\begin{array}{c}\text { Perubahan } \\
\left(\mathbf{m}^{2}\right)\end{array}$ & Perubahan \\
\hline \multirow[t]{2}{*}{$\begin{array}{c}\text { Pemanfaatan } \\
\text { Lahan }\end{array}$} & $\begin{array}{c}\text { Pemanfaatan } \\
\text { Lahan }\end{array}$ & & \\
\hline & Kegiatan Ekonomi & 472.956 & - \\
\hline \multirow{3}{*}{$\begin{array}{l}\text { Kegiatan } \\
\text { Ekonomi }\end{array}$} & Kegiatan Sosial & 2.800 & 0.19 \\
\hline & $\begin{array}{l}\text { Tidak ada } \\
\text { Pemanfaatan }\end{array}$ & 715 & 0.04 \\
\hline & Permukiman & 102.863 & - \\
\hline \multirow[t]{3}{*}{ Permukiman } & Kegiatan Ekonomi & 23.416 & 1.62 \\
\hline & $\begin{array}{l}\text { Tidak ada } \\
\text { Pemanfaatan }\end{array}$ & 5.403 & 0.37 \\
\hline & $\begin{array}{l}\text { Tidak Ada } \\
\text { Pemanfaatan }\end{array}$ & 532.494 & - \\
\hline \multirow{3}{*}{$\begin{array}{l}\text { Tidak Ada } \\
\text { Pemanfaatan }\end{array}$} & Kegiatan Ekonomi & 182.625 & 12.69 \\
\hline & Kegiatan Sosial & 1.446 & 0.10 \\
\hline & Permukiman & 625 & 0.04 \\
\hline Kegiatan Sosial & Kegiatan Sosial & 15.301 & - \\
\hline
\end{tabular}

Tabel 4. Pemanfaatan Ruang Tahun 2018 Jalan Soekarno Hatta

\begin{tabular}{|c|c|c|c|c|}
\hline No & \multicolumn{3}{|c|}{ Pemanfaatan Ruang } & Luas $\left(\mathbf{m}^{2}\right)$ \\
\hline 1 & \multicolumn{3}{|c|}{ Kegiatan Ekonomi } & 678.9 \\
\hline 2 & \multicolumn{3}{|c|}{ Kegiatan Sosial } & 19.5 \\
\hline 3 & \multicolumn{3}{|c|}{ Permukiman } & 103.4 \\
\hline 4 & \multicolumn{3}{|c|}{ Tidak Ada Pemanfaatan } & 538.6 \\
\hline \multicolumn{5}{|c|}{$\begin{array}{l}\text { Tabel 5. Perubahan Pemanfaatan Ruang Tahun } \\
\text { 2008-2013 koridor Jalan SoekarnoHatta }\end{array}$} \\
\hline \multicolumn{3}{|c|}{ Perubahan } & \multirow{3}{*}{$\begin{array}{c}\text { Luas } \\
\text { Perubahan } \\
\left(\mathbf{m}^{2}\right)\end{array}$} & \multirow{2}{*}{$\begin{array}{c}\text { Persentase } \\
\text { Perubahan } \\
(\%)\end{array}$} \\
\hline & 2008 & 2013 & & \\
\hline & $\begin{array}{l}\text { nanfaatan } \\
\text { Lahan }\end{array}$ & $\begin{array}{c}\text { Pemanfaatan } \\
\text { Lahan }\end{array}$ & & \\
\hline $\begin{array}{l}\text { Keg } \\
\text { Eko }\end{array}$ & atan & Kegiatan Ekonomi & 376.770 & - \\
\hline \multirow{2}{*}{\multicolumn{2}{|c|}{ Permukiman }} & Permukiman & 114.223 & - \\
\hline & & $\begin{array}{l}\text { Tidak Ada } \\
\text { Pemanfaatan }\end{array}$ & 740.672 & - \\
\hline \multirow{3}{*}{\multicolumn{2}{|c|}{$\begin{array}{l}\text { Tidak Ada } \\
\text { Pemanfaatan }\end{array}$}} & Kegiatan Ekonomi & 97.082 & 6.75 \\
\hline & & Kegiatan Sosial & 12.767 & 0.88 \\
\hline & & Permukiman & 18.793 & 1.30 \\
\hline Keg & atan Sosial & Kegiatan Sosial & 2.533 & - \\
\hline
\end{tabular}

Tabel 6. Perubahan Pemanfaatan Ruang Tahun 2013-2018 koridor Jalan SoekarnoHatta Perubahan Luas Persentase

Tabel 7. Perubahan Pemanfaatan RuangTahun 2008-2018 koridorJalan SoekarnoHatta

$\begin{array}{ccc}\text { Perubahan } & \begin{array}{c}\text { Luas } \\ \text { Perubahan }\end{array} & \begin{array}{l}\text { Persentase } \\ \text { Perubahan }\end{array}\end{array}$

03.488

2008 $\left(\mathbf{m}^{2}\right)$ (\%)

\begin{tabular}{llrr}
\multicolumn{1}{c}{$\begin{array}{c}\text { Pemanfaatan } \\
\text { Lahan }\end{array}$} & \multicolumn{1}{c}{$\begin{array}{c}\text { Pemanfaatan } \\
\text { Lahan }\end{array}$} & & 0 \\
Kegiatan & Kegiatan Ekonomi & 377.579 & 0.05 \\
Ekonomi & Kegiatan Sosial & 727 & 0.04 \\
& Tidak ada & 715 & 0 \\
& Pemanfaatan & & \\
& Permukiman & & 1.38 \\
& Kegiatan Ekonomi & 19.978 & 0.13 \\
Permukiman & Tidak ada & 1.940 & 0 \\
& $\begin{array}{l}\text { Pemanfaatan } \\
\text { Tidak Ada }\end{array}$ & 535.985 & 19.56 \\
& $\begin{array}{l}\text { Pemanfaatan } \\
\text { Kegiatan Ekonomi }\end{array}$ & 281.439 & 1.13 \\
Pemanfaatan & Kegiatan Sosial & 16.286 & 0.72 \\
\hline & Permukiman & 10.439 & 0.533 \\
\hline
\end{tabular}

Perubahan Pemanfaatan ruang di koridor ruas Jalan Soekarno Hatta Kota Pekanbaru tahun 20082018 mengalami perubahan yang signifikan. Perubahan yang terjadi sebagian besar adalah munculnya kawasan baru dari lahan yang belum 
di manfaaatkan telah berubah fungsinya. Perubahan pemanfaatan lahan yang sangat dominan adalah pemanfaatan lahan untuk kegiatan ekonomi sebesar 19,56\%.

\section{KESIMPULAN}

Perubahan pemanfaatan ruang yang terjadi pada koridor ruas Jalan Soekarno Hatta Kota Pekanbaru sejak Tahun 2008-2018 mengalami perubahan yang cukup signifikan. Perubahan pemanfaatan yang paling dominan adalah untuk pemanfaatan kegiatan ekonomi, yaitu terjadipenambahan luas sebesar $301.455 \mathrm{~m}^{2}$ atau $20 \%$, selanjutnya terjadi peningkatan pemanfaatan ruang untuk kegiatan sosial bertambah sebesar $17.014 \mathrm{~m}^{2}$ atau $1.1 \%$. Perubahan pemanfaatan ruang di koridor ruas Jalan Soekarno Hatta Kota Pekanbaru cenderung kearah kegiatan komersial. Hal ini terlihat dari meningkatnya jumlah lahan yang di manfaatkan untuk kegiatan perdagangan dan jasa yang semakin meluas pada kawasan strategis koridor.

\section{DAFTAR PUSTAKA}

Asteriani, F. Jannah,H.Nugraha,I.Cahyaningsih,C dan Tanjung,M.H. 2019.Morphological Analysis of Siak Sri Indrapura City in 2005-2018.Journal of Phisic : Conference Series Vol. 1424 No.1

Amri, Saepul. 2015. Analisis Perwujudan Pemanfaatan Ruangdi SUB Wilayah Kota VII (SWK VII) Kota Sukabumi Provinsi Jawa Barat. Universitas Pakuan. Jawa Barat

Pontoh, Nia K. 2008. Pengantar Perencanaan Perkotaan. Institut Teknologi Bandung : Bandung.

Republik Indonesia.2007.Undang- Undang No.26 Tahun 2007 Tentang Penataan Ruang.Sekretariatan Negara.Jakarta

Sugiyono. 2012. Metode Penelitian Kuantitatif Kualitatif dan R\&D. Bandung: Alfabeta.

Sugiyono. 2014. Metode Penelitian Pendidikan pendekatan Kuantitatif, Kualitatif, dan $R \& D$. Bandung: Alfabeta.

Wardhana, I.W and Haryanto, R.2016.Kajian
Pemanfaatan Ruang Kegiatan Komersial Koridor Jalan Taman Siswa Kota Semarang. Jurnal Pengembangan Kota vol. 4 no.1.Universitas Diponegoro. Semarang.

Yunus, H.S. 2000. Struktur Tata Ruang Kota. Yogyakarta: Fakultas Geografi UGM.

Yunus, H.S. 2005. Struktur Tata Ruang Kota. Yogyakarta: Pustaka Pelajar. 